\title{
The ecological role of biodiversity in agroecosystems
}

\author{
Miguel A. Altieri* \\ Department of Environmental Science, Policy and Management, University of California, 201 Wellman, Berkeley, CA 94720, USA
}

\begin{abstract}
Increasingly research suggests that the level of internal regulation of function in agroecosystems is largely dependent on the level of plant and animal biodiversity present. In agroecosystems, biodiversity performs a variety of ecological services beyond the production of food, including recycling of nutrients, regulation of microclimate and local hydrological processes, suppression of undesirable organisms and detoxification of noxious chemicals. In this paper the role of biodiversity in securing crop protection and soil fertility is explored in detail. It is argued that because biodiversity mediated renewal processes and ecological services are largely biological, their persistence depends upon the maintenance of biological integrity and diversity in agroecosystems. Various options of agroecosystem management and design that enhance functional biodiversity in crop fields are described. (C)1999 Elsevier Science B.V. All rights reserved.
\end{abstract}

Keywords: Agroecology; Antagonists; Biodiversity; Biological control; Organic farming; Sustainable agriculture; Traditional farming

\section{Introduction}

Biodiversity refers to all species of plants, animals and micro-organisms existing and interacting within an ecosystem (Vandermeer and Perfecto, 1995). Natural biodiversity has provided the foundation for all agricultural plants and animals. The entire range of the domestic crops used in world agriculture is derived from wild species that have been modified through domestication, selective breeding and hybridization. Most remaining world centers of diversity contain populations of variable and adaptable landraces as well as wild and weedy relatives of crops, all of which provide valuable genetic resources for crop improvement (Harlan, 1975).

In addition to producing valuable plants and animals, biodiversity performs many ecological services. In natural ecosystems, the vegetative cover of a forest

\footnotetext{
* Fax: +1-510-642-7428

E-mail address: agroeco3@nature.berkeley.edu (M.A. Altieri)
}

or grassland prevents soil erosion, replenishes ground water and controls flooding by enhancing infiltration and reducing water runoff (Perry, 1994). In agricultural systems, biodiversity performs ecosystem services beyond production of food, fiber, fuel, and income. Examples include recycling of nutrients, control of local microclimate, regulation of local hydrological processes, regulation of the abundance of undesirable organisms, and detoxification of noxious chemicals. These renewal processes and ecosystem services are largely biological, therefore their persistence depends upon maintenance of biological diversity (Altieri, 1994). When these natural services are lost due to biological simplification, the economic and environmental costs can be quite significant. Economically, in agriculture the burdens include the need to supply crops with costly external inputs, because agroecosystems deprived of basic regulating functional components lack the capacity to sponsor their own soil fertility and pest regulation. Often the costs involve a reduction in the quality of life due to de- 
creased soil, water, and food quality when pesticide and/or nitrate contamination occurs.

The net result of biodiversity simplification for agricultural purposes is an artificial ecosystem that requires constant human intervention, whereas in natural ecosystems the internal regulation of function is a product of plant biodiversity through flows of energy and nutrients, and this form of control is progressively lost under agricultural intensification (Swift and Anderson, 1993). Thus commercial seed-bed preparation and mechanized planting replace natural methods of seed dispersal; chemical pesticides replace natural controls on populations of weeds, insects, and pathogens; and genetic manipulation replaces natural processes of plant evolution and selection. Even decomposition is altered because plant growth is harvested and soil fertility maintained, not through nutrient recycling, but with fertilizers (Cox and Atkins, 1979).

Thus modern agricultural systems have become productive but only by being highly dependent on external inputs. A growing number of scientists, farmers and the general public fear for the long-term sustainability of such highly input-dependent and ecologically simplified food production systems. Questions are being raised about the growing dependence of modern farming on non-renewable resources, the loss of biodiversity, the loss of land through soil erosion and the heavy reliance on chemical fertilizers and pesticides. Farm chemicals are questioned on grounds of cost but their widespread use also has implications for human and animal health, food quality and safety and environmental quality. The commercial agricultural sectors of developing countries suffer from similar problems but the greater challenge for them is to determine new ways to increase small farm productivity that not only benefit the rural poor under marginal agricultural conditions (hillsides, rainfed and marginal soils), but also conserve and regenerate the resource base (Altieri, 1995).

In both scenarios, the development of agroecological technologies and systems which emphasize the conservation-regeneration of biodiversity, soil, water and other resources is urgently needed to meet the growing array of socioeconomic and environmental challenges. Enhancing functional biodiversity in agroecosystems is a key ecological strategy to bring sustainability to production. As a way of illustrat- ing this point, the role of biodiversity (predators, parasitoids, antagonists and soil microflora and microfauna) in securing crop protection and soil fertility is explored in this paper.

\section{The nature of biodiversity in agroecosystems}

Modern agriculture implies the simplification of the structure of the environment over vast areas, replacing nature's diversity with a small number of cultivated plants and domesticated animals. In fact, the world's agricultural landscapes are planted mostly with some 12 species of grain crops, 23 vegetable crop species, and about 35 fruit and nut crop species (Fowler and Mooney, 1990); i.e., no more than 70 plant species spread over approximately 1440 million ha of presently cultivated land in the world, a sharp contrast with the diversity of plant species found within 1 ha of a tropical rain forest, which typically contains over 100 species of trees (Perry, 1994). Genetically, modern agriculture is shockingly dependent on a handful of varieties for its major crops. For example, in the US, $60-70 \%$ of the total bean area is planted with $2-3$ bean varieties, $72 \%$ of the potato area with four varieties and $53 \%$ of the cotton area with three varieties (National Academy of Sciences, 1972). Researchers have repeatedly warned about the extreme vulnerability associated with this genetic uniformity.

In contrast, biodiversity is not foreign to traditional farmers in the Third World. In fact, a salient feature of traditional farming systems is their degree of plant diversity in the form of polycultures and/or agroforestry patterns. In fact the species richness of all biotic components of traditional agroecosystems is comparable with that of many natural ecosystems. These systems offer a means of promoting diversity of diet and income, stability of production, minimization of risk, reduced insect and disease incidence, efficient use of labor, intensification of production with limited resources, and maximization of returns under low levels of technology. Traditional, multiple cropping systems are estimated to still provide as much as $15-20 \%$ of the world's food supply. In Latin America farmers grow $70-90 \%$ of their beans with maize, potatoes and other crops. Maize is intercropped on 60\% of the region's maize-growing area (Francis, 1986). 
Traditional cropping systems are also genetically diverse, containing numerous varieties of domesticated crop species as well as their wild relatives. In the Andes, farmers cultivate as many as 50 potato varieties in their fields. Maintaining genetic diversity appears to be of even greater importance as land becomes more marginal, and hence farming more risky. In Peru, for example, the number of potato varieties cultivated increases with the altitude of the land farmed. Genetic diversity confers at least partial resistance to diseases that are specific to particular strains of crops and allows farmers to exploit different soil types and micro-climates for a variety of nutritional and other uses (Brush, 1982).

On the other hand, traditional agroforestry systems throughout the tropics commonly contain well over 100 annual and perennial plant species per field, species used for construction materials, firewood, tools, medicine, livestock feed, and human food. Besides providing useful products, the trees in these systems minimize nutrient leaching and soil erosion and restore key nutrients by pumping them from the lower soil strata (Marten, 1986). Examples include the home gardens of the Huastec Indians in Mexico, and the agroforestry systems of the Amazonian Kayapo and Bora Indians (Toledo, 1985).

Intercropping, agroforestry, shifting cultivation and other traditional farming methods mimic natural ecological processes, and their sustainability lies in the ecological models they follow. This use of natural analogies suggests principles for the design of agricultural systems that make effective use of sunlight, soil nutrients, rainfall, and biological resources. Many scientists have now recognized how traditional farming systems can be models of efficiency as these systems incorporate careful management of soil, water, nutrients, and biological resources. The study of these systems is now offering important guidelines for water-use efficiency, pest control, soil conservation, and fertility management of the kind that subsistence farmers can afford (Gliessman, 1995).

The type and abundance of biodiversity in agriculture will differ across agroecosystems which differ in age, diversity, structure, and management. In fact, there is great variability in basic ecological and agronomic patterns among the various dominant agroecosystems. In general, the degree of biodiversity in agroecosystems depends on four main characteristics of the agroecosystem (Southwood and Way, 1970):

1. The diversity of vegetation within and around the agroecosystem.

2. The permanence of the various crops within the agroecosystem.

3. The intensity of management.

4. The extent of the isolation of the agroecosystem from natural vegetation.

The biodiversity components of agroecosystems can be classified in relation to the role they play in the functioning of cropping systems (Fig. 1). According to this, agricultural biodiversity can be grouped as follows (Swift and Anderson, 1993):

Productive biota: crops, trees and animals chosen by farmers which play a determining role in the diversity and complexity of the agroecosystem.

Resource biota: organisms that contribute to productivity through pollination, biological control, decomposition, etc.

Destructive biota: weeds, insect pests, microbial pathogens, etc. which farmers aim at reducing through cultural management.

According to Vandermeer and Perfecto (1995), two distinct components of biodiversity can be recognized in agroecosystems. The first component, planned biodiversity, is the biodiversity associated with the crops and livestock purposely included in the agroecosystem by the farmer, and which will vary depending on the management inputs and crop spatial/temporal arrangements. The second component, associated biodiversity, includes all soil flora and fauna, herbivores, carnivores, decomposers, etc. that colonize the agroecosystem from surrounding environments and that will thrive in the agroecosystem depending on its management and structure. Fig. 2 illustrates the relationship of both biodiversity components. Planned biodiversity has a direct function, as illustrated by the bold arrow connecting the planned biodiversity box with the ecosystem function box. Associated biodiversity also has a function, but it is mediated through planned biodiversity. Thus, planned biodiversity also has an indirect function, illustrated by the dotted arrow in the figure, which is realized through its influence on the associated biodiversity. For example, the trees in an agroforestry system create shade, which makes it possible to grow only sun-intolerant crops. So the direct function of this second species (the trees) is to create shade. Yet, along with the trees might come 


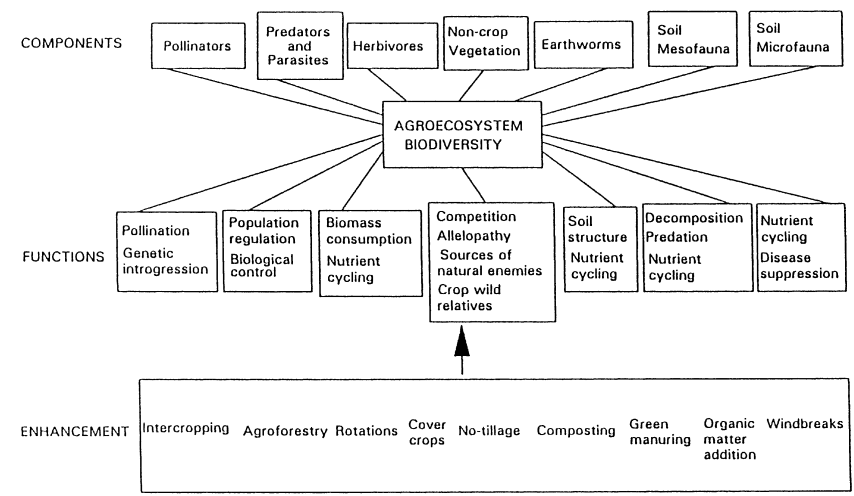

Fig. 1. The components, functions, and enhancement strategies of biodiversity in agroecosystems (Altieri, 1994).

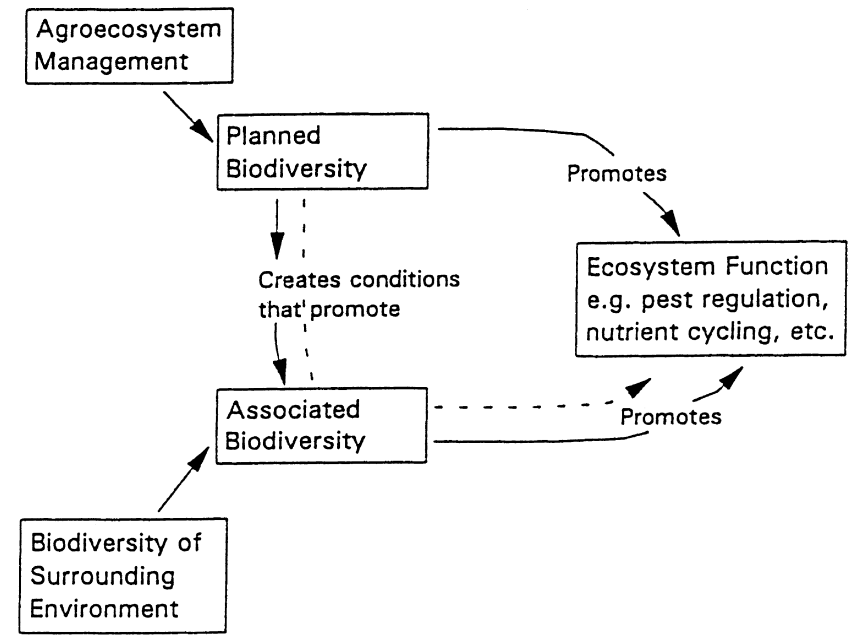

Fig. 2. The relationship between planned biodiversity (that which the farmer determines, based on management of the agroecosystem) and associated (that which colonizes the agroecosystem after it has been set up by the farmer) and how the two promote ecosystem function (modified from Vandermeer and Perfecto, 1995).

wasps that suck out the nectar from the tree's flowers. These wasps may in turn be the natural parasitoids of pests that normally attack the crops. The wasps are part of the associated biodiversity. The trees, then, create shade (direct function) and attract wasps (indirect function) (Vandermeer and Perfecto, 1995).

The key is to identify the type of biodiversity that is desirable to maintain and/or enhance in order to carry out ecological services, and then to determine the best practices that will encourage the desired biodiversity components. Fig. 3 shows that there are many agricultural practices and designs that have the potential to enhance functional biodiversity, and others that negatively affect it. The idea is to apply the best management practices in order to enhance or regenerate the kind of biodiversity that can not only subsidize the sustainability of agroecosystems by providing ecological services such as biological pest control, but also nutrient cycling, water and soil conservation, etc.

Thus, a main strategy in agroecology is to exploit the complementarities and synergisms that result from various combinations of crops, trees and animals in spatial and temporal arrangements such as polycultures, agroforestry systems and crop-livestock mixtures. Throughout the world agroecologists should encourage those agricultural practices which increase the abundance and diversity of above and below-ground 


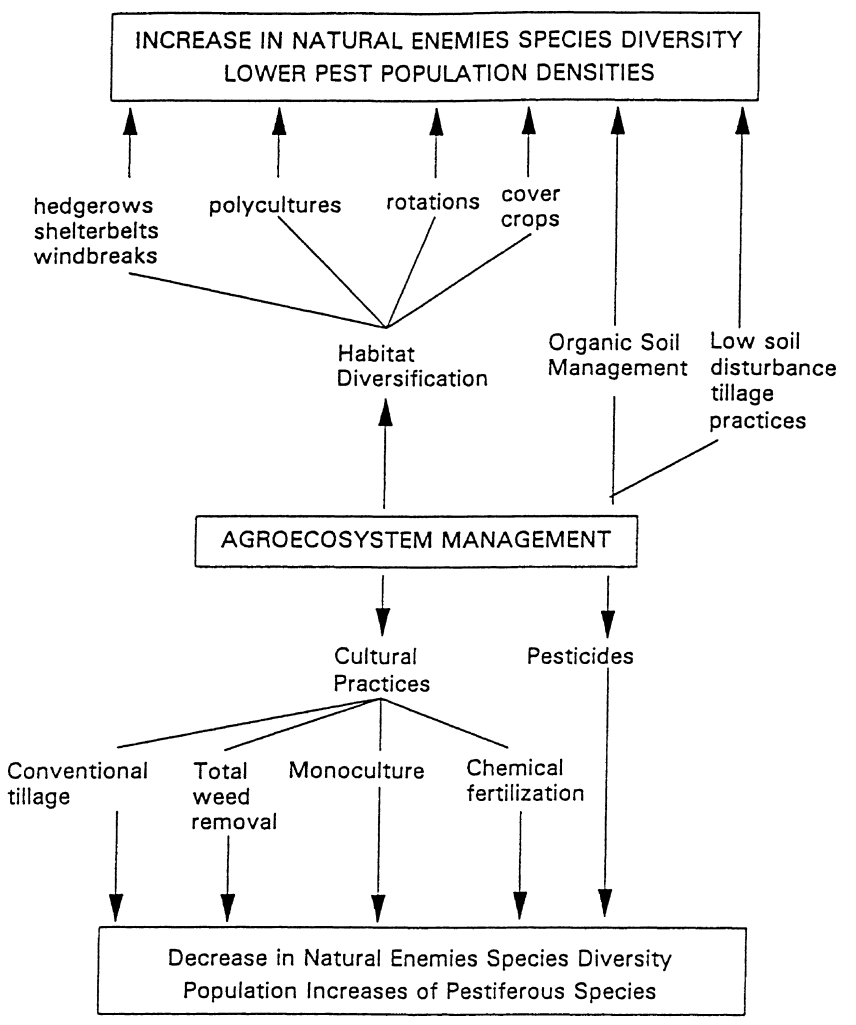

Fig. 3. The effects of agroecosystem management and associated cultural practices on the biodiversity of natural enemies and the abundance of insect pests.

organisms, which in turn provide key ecological services to agroecosystems (Reijntjes et al., 1992).

\section{Biodiversity and insect pest management}

Nowhere are the consequences of biodiversity reduction more evident than in the realm of agricultural pest management. The instability of agroecosystems, which is manifested as the worsening of most insect pest problems, is increasingly linked to the expansion of crop monocultures at the expense of the natural vegetation, thereby decreasing local habitat diversity (Altieri and Letourneau, 1982). Plant communities that are modified to meet the special needs of humans become subject to heavy pest damage and generally the more intensely such communities are modified, the more abundant and serious the pests. The inherent self-regulation characteristics of natural communities are lost when humans modify such com- munities through the shattering of the fragile thread of community interactions. Agroecologists maintain that this breakdown can be repaired by restoring the shattered elements of community homeostasis through the addition or enhancement of biodiversity (Altieri, 1994).

For years, ecologists have debated the assumption that increased diversity fosters stability. Critical theoretical reviews on this subject are abundant in the literature, as well as reviews that use agricultural examples to bolster the theory (Andow, 1991). Most studies conclude that by mixing certain plant species with the primary host of a specialized herbivore gives a fairly consistent result: specialized species usually exhibit higher abundance in monocultures than in polycultures. In a recent review, Andow (1991) identified 209 published studies that deal with the effects of vegetation diversity in agroecosystems on herbivorus arthropod species. Fifty-two percent of the 287 total herbivore species examined in these studies were 
found to be less abundant in diversified systems than in monocultures, while only $15.3 \%$ (44 species) exhibited higher densities in polycultures.

Four main ecological hypotheses have been offered to explain why insect communities in agroecosystems can be stabilized by constructing vegetational architectures that support natural enemies and/or directly inhibit pest attack (Altieri, 1994). The literature is full of examples of experiments documenting that diversification of cropping systems often leads to reduced herbivore populations. The studies suggest that the more diverse the agroecosystems and the longer this diversity remains undisturbed, the more internal links develop to promote greater insect stability. It is clear, however, that the stability of the insect community depends not only on its trophic diversity, but also on the actual density-dependence nature of the trophic levels (Southwood and Way, 1970). In other words, stability will depend on the precision of the response of any particular trophic link to an increase in the population at a lower level.

Although most experiments have documented insect population trends in single versus complex crop habitats, a few have concentrated on elucidating the nature and dynamics of the trophic relationships between plants and herbivores, and herbivores and their natural enemies in diversified agroecosystems. Several types of studies have been developed (Altieri, 1994, 1995; Altieri and Letourneau, 1982, 1984):

Crop-weed-insect interaction studies: evidence indicates that weeds influence the diversity and abundance of insect herbivores and associated natural enemies in crop systems. Certain weeds (mostly Umbelliferae, Leguminosae and Compositae) play an important ecological role by harboring and supporting a complex of beneficial arthropods that aid in suppressing pest populations.

Insect dynamics in annual polycultures: overwhelming evidence suggests that polycultures support a lower herbivore load than monocultures. One factor explaining this trend is that relatively more stable natural enemy populations can persist in polycultures due to the more continuous availability of food sources and micro habitats. The other possibility is that specialized herbivores are more likely to find and remain on pure crop stands that provide concentrated resources and monotonous physical conditions.
Herbivores in complex perennial crop systems: most of these studies have explored the effects of the manipulation of ground cover vegetation on insect pests and associated enemies. The data indicate that orchards with rich floral undergrowth exhibit a lower incidence of insect pests than clean cultivated orchards, mainly because of an increased abundance and efficiency of predators and parasitoids. In some cases, ground cover directly affects herbivore species which discriminate among trees with and without cover beneath.

The effects of adjacent vegetation: these studies have documented the dynamics of colonizing insect pests that invade crop fields from bordering vegetation, especially when the vegetation is botanically related to the crop. A number of studies document the importance of adjoining wild vegetation in providing alternate food and habitat to natural enemies that move into nearby crops (Boatman, 1994).

The available literature suggests that the design of vegetation management strategies must include knowledge and consideration of (1) crop arrangement in time and space, (2) the composition and abundance of non crop vegetation within and around fields, (3) the soil type, (4) the surrounding environment, and (5) the type and intensity of management. The response of insect populations to environmental manipulations depends upon their degree of association with one or more of the vegetational components of the system. Extension of the cropping period or planning temporal or spatial cropping sequences may allow naturally occurring biological control agents to sustain higher population levels on alternate hosts or prey and to persist in the agricultural environment throughout the year.

Since farming systems in a region are managed over a range of energy inputs, levels of crop diversity, and successional stages, variations in insect dynamics are likely to occur and maybe difficult to predict. However, based on current ecological and agronomic theory, low pest potentials may be expected in agroecosystems that exhibit the following characteristics (Altieri, 1994; Altieri and Letourneau, 1982, 1984):

1. High crop diversity through mixing crops in time and space.

2. Discontinuity of monocultures in time through rotations, use of short maturing varieties, use of crop-free or preferred host-free periods, etc. 
3. Small, scattered fields creating a structural mosaic of adjoining crops and uncultivated land which potentially provide shelter and alternative food for natural enemies. Pests also may proliferate in these environments depending on plant species composition. However, the presence of low levels of pest populations and/or alternate hosts may be necessary to maintain natural enemies in the area.

4. Farms with a dominant perennial crop component. Orchards are considered to be semi-permanent ecosystems, and more stable than annual cropping systems. Since orchards suffer less disturbance and are characterized by greater structural diversity, possibilities for the establishment of biological control agents are generally higher, especially if floral undergrowth diversity is encouraged.

5. High crop densities or the presence of tolerable levels of specific weed species.

6. High genetic diversity resulting from the use of variety mixtures or crop multilines.

The above generalizations can serve in the planning of a vegetation management strategy in agroecosystems. However, they must take into account local variations in climate, geography, crops, local vegetation, inputs, pest complexes, etc. which might increase or decrease the potential for pest development under certain vegetation management conditions. The selection of component plant species can also be critical. Systematic studies on the 'quality' of plant diversification with respect to the abundance and efficiency of natural enemies are needed. As pointed out by Southwood and Way (1970), what seems to matter is 'functional' diversity and not diversity per se. These effects of diversification can only be determined experimentally across a whole range of agroecosystems. The task is indeed overwhelming since enhancement techniques must necessarily be site specific.

\section{Manipulating biodiversity at the landscape level}

Most studies of the effects of biodiversity enhancement on insect populations have been conducted at the field level, rarely considering larger scales such as the landscape level. It is well known that spatial patterns of landscapes influence the biology of arthropods both directly and indirectly. One of the principal distinguishing characteristics of modern agricultural landscape is the large size and homogeneity of crop monocultures which fragment the natural landscape. This can directly affect abundance and diversity of natural enemies, as the larger the area under monoculture the lower the viability of a given population (Fig. 4). Therefore reintroducing a mosaic structure into agricultural landscape composed of woodlots, fencerows, hedgerows, wetlands, farmyards, etc. can lead to the creation of multiple habitats for reproduction, feeding and sheltering for a number of beneficial arthropod species (Altieri, 1994).

One way to reintroduce biodiversity into large-scale monocultures is by establishing vegetationally diverse field margins and/or hedgerows which may serve as biological corridors allowing the movement and distribution of useful arthropod biodiversity. There is wide acceptance of the importance of field margins as reservoirs of the natural enemies of crop pests. Many studies have demonstrated increased abundance of natural enemies and more effective biological control where crops are bordered by wild vegetation. These habitats may be important as overwintering sites for natural enemies and may provide increased resources such as alternative prey/hosts, pollen and nectar for parasitoids and predators from flowering plants (Landis, 1994).

Several data show that many polyphagous predators have significantly higher densities close to margins $(15-30 \mathrm{~m})$. Similar effects have been observed with carabids in fields containing specially designed margins (beetle banks) which enhance predator densities within neighboring crop rows. The distances at which the natural enemies penetrate the crop could become the basis for optimizing the spacing of field margins within monocultures (Boatman, 1994).

Given the high edge-to-area ratio in the margins, these features are expected to have a high degree of interaction with adjacent crops, thereby providing protection against insect pests within the area of influence of the corridors. By documenting the effects of corridors on arthropod distribution and abundance it may be possible to determine the length, width, distance, and frequency of corridors needed to maintain a level of functional biodiversity which will provide the necessary crop protection without the need for pesticides. In fact, field margins can be designed as a complex of corridors linking crop habitats, thereby enhancing the dispersal of natural enemies and thus stabilizing pest populations (Fry, 1995). 


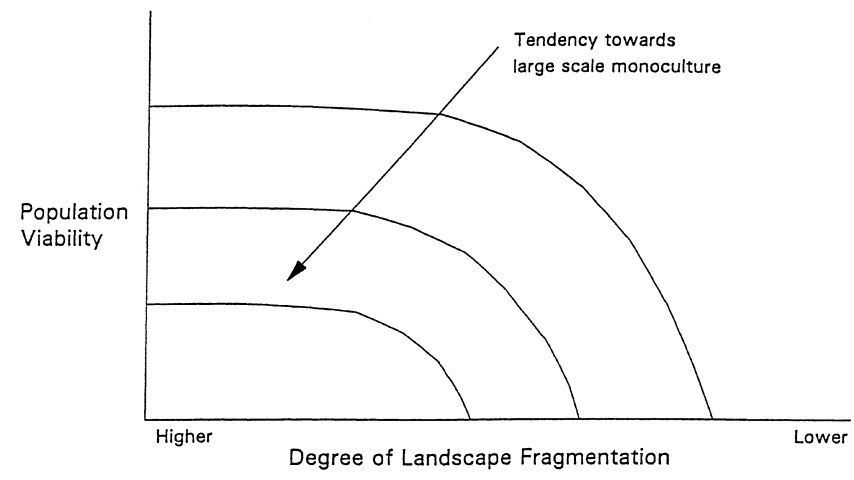

Fig. 4. The effects of landscape fragmentation on the expected viability of natural enemy populations in agroecosystems of varying scales and levels of artificialization.

A system of corridors can also have positive effects on the overall system by interrupting disease inoculum dispersion, by serving as barriers to insect pest movement, by modifying microclimate through interception of air currents, by influencing the flow of nutrients, materials and water and by providing habitat for wildlife. The most important function of corridors, however, arises through their manipulation, which can be an important first step in reintroducing biodiversity into large scale agroecosystems where natural vegetation patches have been virtually eliminated (Perry, 1994).

\section{Biodiversity, soil fertility and plant health}

A key feature of annual cropping systems is the nature and frequency of soil disturbance regimes. Periodic tillage and planting continually reverts the tilled area to an earlier stage of ecological succession. Physical disturbance of the soil caused by tillage and residue management is a crucial factor in determining soil biotic activity and species diversity in agroecosystems. Tillage usually disturbs at least $15-25 \mathrm{~cm}$ of the soil surface and replaces stratified surface soil horizons with a tilled zone more homogeneous with respect to physical characteristics and residue distribution. The loss of a stratified soil microhabitat causes a decrease in the density of species that inhabit agroecosystems. Such soil biodiversity reductions are negative because the recycling of nutrients and proper balance between organic matter, soil organisms and plant diversity are necessary components of a productive and ecologically balanced soil environment (Hendrix et al., 1990).
Soil biomass consists of microbes (fungi, bacteria and actinomycetes) and animals such as nematodes, mites, collembola, diplopoda, earthworms and arthropods (Davies, 1973). A square meter of an organic temperate agricultural soil may contain 1000 species of organisms with population densities in the order of $10^{6} / \mathrm{m}^{2}$ for nematodes, $10^{5} / \mathrm{m}^{2}$ for micro arthropods and $10^{4} / \mathrm{m}^{2}$ for other invertebrate groups. One gram of soil may contain over a thousand fungal hyphae and up to a million or more individual bacterial colonies. Energy, carbon, nitrogen and other nutrient fluxes through the soil decomposing subsystem are dominated by fungi and bacteria, although invertebrates play a certain role in $\mathrm{N}$ flux (Swift and Anderson, 1993).

In their role as regulators of soil ecosystem processes, soil organisms perform a number of vital functions (Paoletti et al., 1994; Table 1):

decomposing litter and cycling nutrients,

converting atmospheric nitrogen into organic forms, and reconverting organic nitrogen to gaseous nitrogen,

suppressing soil-borne pathogens through antagonism,

synthesizing enzymes, vitamins, hormones, vital chelators and allelochemicals that regulate populations and processes,

altering soil structure,

directly interacting with plants through mutualism, commensalisms, competition, and pathogenesis.

The activity of soil microbes influences nutrient availability directly and indirectly. A direct effect is the breakdown of organic matter and subsequent re- 
Table 1

Influences of soil biota on soil processes in ecosystems (Hendrix et al., 1990)

\begin{tabular}{lll}
\hline & Nutrient Cycling & Soil Structure \\
\hline $\begin{array}{l}\text { Microflora (fungi, bacteria, actino- } \\
\text { mycetes) }\end{array}$ & $\begin{array}{l}\text { Catabolize organic matter; mineralize and } \\
\text { immobilize nutrients } \\
\text { Microfauna (Acarina, Collembola) }\end{array}$ & $\begin{array}{l}\text { Pegulate bacterial and fungal populations; } \\
\text { alter nutrient turnover } \\
\text { hyphae entangle particles onto aggregates }\end{array}$ \\
$\begin{array}{llll}\text { Mesofauna (Acarina, Collembola, } \\
\text { enchytraeids) }\end{array}$ & $\begin{array}{l}\text { Regulate fungal and microfaunal popula- } \\
\text { tions; alter nutrient turnover; fragment plant } \\
\text { residues }\end{array}$ & $\begin{array}{l}\text { Produce fecal pellets; create biopores; promote hu- } \\
\text { mification }\end{array}$ \\
$\begin{array}{l}\text { Macrofauna } \\
\text { millipedes, earthworms, etc.) }\end{array}$ & $\begin{array}{l}\text { Fragment plant residues; stimulate microbial } \\
\text { activity }\end{array}$ & $\begin{array}{l}\text { Mix organic and mineral particles; redistribute or- } \\
\text { ganic matter and micro-organisms; create biopores; } \\
\text { promote humification; produce fecal pellets }\end{array}$ \\
\hline
\end{tabular}

lease of nutrients not used in cell building and maintenance processes. These 'extra' nutrients are available to plants. Also, since the microbial biomass itself is a relatively labile fraction of the soil organic matter, nutrients in biomass become available as dead microbial cells and are attacked by other microbes. Indirect effects result from the interaction of microbial by-products with soil constituents and nutrients. Examples of the effect of by-products on P availability are well documented (Doran and Werner, 1990).

Given the ecological services provided by soil biodiversity (Table 2), soil organisms are crucial for the sustainability of agroecosystems. It is, therefore, important to define and encourage agricultural practices that increase abundance and diversity of soil organisms by enhancing habitat conditions or resource availability. Sustained agricultural productivity may depend on the selection of management practices that enhance soil biological activities involved in the fixation of atmospheric N, recycling of carbon and nutrients, and suppression of soil pathogens.

\subsection{Enhancing biota for soil fertility}

The major influences of agricultural management practices on soil biological activity relate to nutrient cycling, changes in $\mathrm{C}$ and $\mathrm{N}$ inputs, the soil physical environment, and negative impacts of synthetic chemical use on soil microbial and faunal activity. Systems that increase below-ground inputs of $\mathrm{C}$ and $\mathrm{N}$ through inclusion of legumes and/or fibrous rooted crops in rotations often increase microbial populations and activity to greater extent than conventional systems using commercial fertilizers. Effects of crop rotations on
Table 2

Beneficial activities of microorganisms in the soil and rhizosphere

Decomposition of plant residues, manures, and organic wastes Humus synthesis

Mineralization of organic N, S, and P

Improved soil aggregation

Increase in the availability of plant nutrients,e.g. $P, M n, F e$,

$\mathrm{Zn}, \mathrm{Cu}$

Symbiotic mycorrhizal associations

Production of organic chelating agents

Oxidation-reduction reactions

Biological nitrogen fixation

Free-living bacteria and bluegreen algae

Associative microorganisms

Symbiotic-legume and nonlegume

Plant growth promotion: changes in seed germination, floral development, root and shoot biomass

Production of plant growth hormones

Protection against root pathogens and pseudopathogens

Enhanced nutrient use efficiency

Control of soil nematodes and insects

Biological control of weeds, e.g. biological herbicides

Biodegradation of synthetic pesticides or industrial contaminants

Enhanced drought tolerance of plants

soil organisms appear to be exerted through quantity and quality of organic inputs and also by providing a period of 'biological break' when no host plants are grown. This is why alfalfa rotations are useful against Heterodera schachtii on sugarbeets and legume rotations are useful against $H$ avenae on cereals. The application of animal manures as nutrient sources generally increases the abundance and activity of soil biota. Microbial and protozoan activity is highest in organically fertilized agricultural soils. Collembola popula- 
tions also tend to increase after manure application. Application of manure also increases the abundance and biomass of earthworms in cropped soils (Doran and Werner, 1990).

Reduced tillage (with surface placement of residues) creates a relatively more stable environment and encourages development of more diverse decomposer communities and slower nutrient turnover. Available evidence suggests that conditions in no-till systems favor a higher ratio of fungi to bacteria, whereas in conventionally tilled systems bacterial decomposers may predominate (Hendrix et al., 1990). High herbicide use in such systems however, can affect soil biodiversity in negative ways.

Residue has an important effect on organic substrate availability and soil micro climatic characteristics. Soils with residues chopped and left as a mulch generally support higher populations of surface feeding earthworms. Soil unprotected by a surface mulch will freeze much faster than mulched soil and earthworm mortality increases in the absence of a gradual period of adjustment to decreasing temperatures (Davies, 1973).

As opposed to conventional tillage, in reduced tillage nutrient reserves are stratified, with concentrations of organic matter and microbial populations being greatest near the soil surface. Stratification of crop residues, organic matter, and soil organisms often slows cycling of $\mathrm{N}$ as compared with conventional tillage with the moldboard plow. Increased microbial immobilization of soluble $\mathrm{N}$ in the surface of reduced tillage soils may require modified fertility or tillage management practices for optimal growth and yield of grain crops (Paoletti et al., 1994).

Soil biotic populations can also be increased through direct introduction of organisms. Earthworms have been commonly introduced in a number of instances for soil conditioning and enhanced soil structure and fertility. Inoculation of seeds or roots with rhizobia, mycorrhizae, and Trichoderma are examples of direct manipulations of microflora to enhance plant performance (Miller, 1990).

A major problem to overcome in the use of inoculations and introductions is ensuring the establishment of the introduced organisms. Competition from a diverse indigenous soil biota may overwhelm introduced organisms. Additionally, limited availability of food resources may result in extinction or emigration.
It may be necessary to add food supplies or organic amendments along with inocula to aid establishment (Miller, 1990).

A key goal of soil biotic management is to manipulate the processes of residue decomposition, nutrient immobilization, and mineralization so that the nutrient release is synchronized with plant growth (Magdoff, 1992). The rationale is that timing of increased nutrient availability to coincide with plant demand will then increase nutrient use efficiency and reduce leaching losses of soluble nutrients (Paoletti et al., 1994). It may be possible to manage soil nutrient availability by manipulating detritus food webs. For example, altering the number of predatory mites to increase or decrease abundance of their fungivorous prey (mites, Collembola, or nematodes) could slow or accelerate fungal decomposition of plant residues (Miller, 1990).

\subsection{Enhancing soil antagonists}

Soils with high fertility and high levels of organic matter seem to enhance natural biocontrol of pathogens, as suggested by the fact that in some soils, pathogens cause little or no disease, despite an apparently favorable environment (Baker and Cook, 1974). In avocado groves in Australia, Phytophtora cinnamoni, which induces severe root rot, failed to develop in soils of avocado groves which were similar in several respects to the nearby soils supporting the native rain forests. The soil in the groves unaffected by root rot was apparently maintained in its highly fertile and biologically active state by the continued application of green manure and use of cover crops. The fertility of rain forest soils results in large part to the rapid turnover of nutrients. In most cases, when the rain forest was cleared and planted to avocados or other crops, the turnover and availability of nutrients decreased, the microbial activity declined, and P. cinnamoni infection became serious (Campbell, 1989).

In some soils disease severity lessens after some years of cropping. Disease decline has been repeatedly illustrated with take-all of wheat induced by Gaumannomyces graminis var. tritici. Typically, severity of take-all increases for the first 2-4 year of wheat monoculture and then decreases in the next years of wheat monoculture (Baker and Cook, 1974). Soils in which disease has declined are generally suppressive 
to further disease development. The suppressiveness is probably due to the soil microbiota, as suppressive soils show higher populations of actinomycetes and bacteria than conducive soils.

When pathogens are not inhibited by naturally occurring antagonists it is possible to enhance biocontrol by adding more effective ones. Agrobacterium tumefaciens var. radiobacter strain 84 and Peniophora gigantea have been successfully introduced and used against crown gall in fruit trees and Fomes annosus in conifers, respectively. Many other micro-organisms have produced beneficial plant responses when introduced into the soil or plant rhizosphere. Examples include Trichoderma spp, Pseudomonas spp, Alcaligenes spp, Agrobacterium tumefaciens and others (Campbell, 1989).

Directed biocontrol involves mass introduction of antagonistic micro-organisms in soil, with or without a food base, to inactive pathogen propagules, thereby reducing their numbers and adversely affecting infection (Table 3). Nematodes also carry a number of fungal and bacterial parasites which can be used to control their numbers (Table 4). There are many ways in which an antagonist can operate: rapid colonization in advance of the pathogens or subsequent competition may lead to niche exclusion, antibiotics may be produced, or there may be mycoparasitism or the lysis of the pathogen. In addition, some micro-organisms may act simply by making the plant grow better, so that even if disease is present, its symptoms are partly masked. Many ectomycorrhizae, which promote phosphorous uptake in plants, form a physical layer or chemical barrier to infections, thereby preventing pathogens from reaching the root surface (Tjamos et al., 1992).

The literature on soil management practices to enhance existing microbial antagonists is voluminous. Organic amendments are recognized as initiators of two important disease control processes: increase in dormancy of propagules and their digestion by soil micro-organisms (Palti, 1981). Organic additions increase the general level of microbial activity and the more microbes that are active, the greater the chances that some of them will be antagonistic to pathogens (Fry, 1982).

Leguminous residues are rich in available nitrogen and carbon compounds, and they also supply vitamins and more complex substrates. Biological activity becomes very intense in response to amendments of this kind and may increase fungistasis and propagule lysis. For example, incorporation of bean straw into soil in Colorado enhanced mycoparasitism of Pythium ultimum by $P$. nunn. Compost of diverse organic materials has been used to control diseases caused by $P h y$ tophthora and Rhizoctonia. The principal controlling factors appear to be the heat of composting as well as antibiotics produced by Trichoderma, Gliocladium, and Pseudomonas (Campbell, 1989).

\section{Conclusion}

The search for self-sustaining, low-input, diversified, and energy-efficient agricultural systems is now a major concern of many researchers, farmers, and policymakers worldwide. A key strategy in sustainable agriculture is to restore functional biodiversity of the agricultural landscape (Altieri, 1994). Biodiversity performs key ecological services and if correctly assembled in time and space can lead to agroecosystems capable of sponsoring their own soil fertility, crop protection and productivity. Diversity can be enhanced in time through crop rotations and sequences and in space in the form of cover crops, intercropping, agroforestry, crop/livestock mixtures, etc. Correct biodiversification results in pest regulation through restoration of natural control of insect pests, diseases and nematodes and also produces optimal nutrient recycling and soil conservation by activating soil biota, all factors leading to sustainable yields, energy conservation, and less dependence on external inputs.

Diversification can also take place outside the farm, e.g., in crop-field boundaries with windbreaks, shelterbelts, and living fences, which can improve habitat for wildlife and beneficial insects, provide sources of wood, organic matter, resources for pollinating bees, and, in addition, modify wind speed and the microclimate (Altieri and Letourneau, 1982). Such structures can also serve as biological corridors for the circulation of biodiversity across large-scale agricultural landscapes.

Different options to diversify cropping systems are available depending on whether the current monoculture systems to be modified are based on annual or perennial crops. Rotation and multiple cropping systems are effective management strategies for annual monocultures. In the case of perennial crops, research 
Table 3

Examples of antagonists used in the biological control of plant pathogens (Schroth and Hancock, 1985)

\begin{tabular}{|c|c|c|c|}
\hline Mechanism & Plant & Plant Pathogen & Antagonist \\
\hline Antibiotic competition/antibiosis & $\begin{array}{l}\text { Many } \\
\text { Corn } \\
\text { Pine } \\
\text { Various } \\
\text { Various } \\
\text { Carnation } \\
\text { Cotton, wheat }\end{array}$ & $\begin{array}{l}\text { Agrobacterium tumefaciens } \\
\text { Fusarium roseum Graminearum } \\
\text { Heterobasidion annosum } \\
\text { Various fungi } \\
\text { Various fungi } \\
\text { F. oxysporium f. sp. dianthi } \\
\text { Gaeumannomyces graminis var. } \\
\text { tritici, Pseudomonas tolaasii, } \\
\text { Fusarium oxysporum f.sp. lini, } \\
\text { Ervinia amylovora, }\end{array}$ & $\begin{array}{l}\text { Avirulent Agrobacterium spp. } \\
\text { Chaetomium globosum } \\
\text { Peniophora gigantea } \\
\text { Trichoderma } \text { spp. } \\
\text { Bacillus subilis } \\
\text { Alcaligenes spp. } \\
\text { Pseudomonas spp. }\end{array}$ \\
\hline & $\begin{array}{l}\text { Apple } \\
\text { Tobacco }\end{array}$ & Pseudomonas solanacearum & $\begin{array}{l}\text { Erwinia herbicola } \\
\text { A virulent strain of } P \text {. solanacearum }\end{array}$ \\
\hline & Many & Various fungi & Gliocladium spp. \\
\hline Competition for attachment sites & Many & A. tumefaciens & Avirulent Agrobacterium spp. \\
\hline Cross protection & $\begin{array}{l}\text { Sweet potato } \\
\text { Cucurbits }\end{array}$ & $\begin{array}{l}\text { F. oxysporum f.sp.batatas } \\
\text { Fusarium solani f.sp. Cucurbitae }\end{array}$ & $\begin{array}{l}\text { Non-pathogenic F.oxysporum } \\
\text { Squash mosaicvirus }\end{array}$ \\
\hline Hyperparasitism & $\begin{array}{l}\text { Many } \\
\text { Sunflower, beans } \\
\text { Lettuce } \\
\text { Sugarbeet } \\
\text { Cucumber, beans } \\
\text { Cucumber } \\
\text { Rye, other cereals }\end{array}$ & $\begin{array}{l}\text { Various fungi } \\
\text { Sclerotinia } \text { spp. } \\
\text { Sclerotinia } \text { spp. } \\
\text { Pythium spp. } \\
\text { Rhizoctonia solani } \\
\text { Mildews } \\
\text { Ergot }\end{array}$ & $\begin{array}{l}\text { Trichoderma spp. } \\
\text { Coniothrium minitans } \\
\text { Sporodesmium sclerotivorum } \\
\text { Pythium oligandrum } \\
\text { Laetisaria arvalis } \\
\text { Ampelomyces grisqualis } \\
\text { F.roseum'heterosporium' }\end{array}$ \\
\hline Hypovirulence & Chestnut & Endothia parasiticaMycovirus & \\
\hline $\begin{array}{l}\text { Parasitism } \\
\text { Predation }\end{array}$ & Soybean & $\begin{array}{l}\text { Pseudomonassyringae pv.glycinea } \\
\text { Various fungi }\end{array}$ & $\begin{array}{l}\text { Bdellovibrio bacteriovorus } \\
\text { Arachnula impatiens }\end{array}$ \\
\hline
\end{tabular}

Table 4

Fungal and Bacterial Parasites of Nematodes (Tjamos et al., 1992)

\begin{tabular}{lll}
\hline Antagonist & Nematode species & Mode of parasitism \\
\hline Arthrobotrys sp. & Several & Traps nematodes in adhesive network of hyphae \\
Dactylella doedycoides & Several & Traps nematodes in a constricting hyphal ring \\
Dactylella oviparasitica & Root rot nematode & Traps nematodes but also parasitizes eggs \\
Dactylaria candida & Meloydogine $\mathrm{sp}$ & Traps nematodes in a three-celled nonconstricting ring \\
$\begin{array}{l}\text { Phialophora heteroderae } \\
\text { Pasteuria penetrana }\end{array}$ & Globodera rostochiensis & Enters cysts of G. rostochiensis \\
Nematophtora gymophyla and & Meloidogyne sp & Bacterial parasite \\
Verticillium chlamydosporium & Heterodera avenae & Fungal parasites \\
$\begin{array}{l}\text { Monacrospium } \text { sp. } \\
\text { Arthrobotrys } \text { sp. }\end{array}$ & Several & Nematode trapping fungi \\
Hirsutella rhossiliensis & Several & Endoparasitic fungi \\
Nematoctorus sp. & Several & Endoparasitic fungi \\
\hline
\end{tabular}

suggests that cover cropping transforms orchards and vineyards into agroecosystems of increasing ecological diversity and stability. In fact, cover crops function as a major 'ecological turn-table' which activates and influences key processes and components of the agroecosystem such as provision of habitat for beneficial insects, activation of soil biology, addition of organic matter, $\mathrm{N}$ fixation, microclimate modification, etc. Novel agroecological approaches aim at breaking the monoculture structure, taking advantage of the effects of the integration of plant and animal biodiversity which enhances complex interactions and synergisms and optimizes ecosystem functions and processes, such as biotic regulation of harmful organisms, 
nutrient recycling, and biomass production and accumulation, thus allowing agroecosystems to sponsor their own functioning. The end result of agroecological design is improved economic and ecological sustainability of the agroecosystem, with proposed management systems specifically in tune with the locally available biodiversity and with the existing environmental and socioeconomic conditions (Altieri, 1995).

\section{References}

Altieri, M.A., Letourneau, D.K., 1982. Vegetation management and biological control in agroecosystems. Crop Protection 1, 405430.

Altieri, M.A., Letourneau, D.K., 1984. Vegetation diversity and insect pest outbreaks. CRC Critical Reviews in Plant Sciences 2, 131-169.

Altieri, M.A., 1994. Biodiversity and Pest Management in Agroecosystems. Haworth Press, New York, 185 pp.

Altieri, M.A., 1995. Agroecology: the Science of Sustainable Agriculture. Westview Press, Boulder, CO, 433 pp.

Andow, D.A., 1991. Vegetational diversity and arthropod population response. Ann. Rev. Entomol. 36, 561-586.

Baker, K.F., Cook, R.J., 1974. Biological Control of Plant Pathogens. Freeman, San Francisco, CA, 433 pp.

Boatman, N., 1994. Field Margins: Integrating Agriculture and Conservation. British Crop Protection Council, Surrey, England, 404 pp.

Brush, S.B., 1982. The natural and human environment in the central Andes. Mountain Res. Dev. 2, 14-38.

Campbell, R., 1989. Biological Control of Microbial Plant Pathogens. Cambridge University Press, Cambridge, 199 pp.

Cox, G.W., Atkins, M.D., 1979. Agricultural Ecology. Freeman, San Francisco, CA, 721 pp.

Davies, N., 1973. A Guide to the Study of Soil Ecology. Andrews, William A. (Ed.), Prentice Hall, Englewood Cliffs, NJ, 198 pp.

Doran, J.W., Werner, M.R., 1990. Management and soil biology. In: Francis, C.A., Flora, C.B., King, L.D. (Eds.), Sustainable Agriculture in Temperate Zones.Wiley, New York, pp. 205-230.

Fowler, C., Mooney, P., 1990. Shattering: Food, Politics and the Loss of Genetic Diversity. University of Arizona Press, Tucson, AZ, 278 pp.

Francis, C.A., 1986. Multiple Cropping Systems. MacMillan, New York, $383 \mathrm{pp}$.

Fry, W.E., 1982. Principles of Plant Disease Management. Academic Press, New York, 378 pp.

Fry, G., 1995. Landscape Ecology of Insect Movement in Arable Ecosystems. In: Glen, D.M. (Ed.), Wiley, Bristol, UK, pp. 236-242.

Gliessman, S.R., 1995. Sustainable agriculture: an agroecological perspective. Advances in Plant Pathology 11, 45-57.
Harlan, J.R., 1975. Our vanishing genetic resources. Science 188, 618-622.

Hendrix, P.F., Crossley, D.A. Jr., Blair, J.M., Coleman, D.C., 1990. Soil biota as components of sustainable agroecosystems. In: Edwards, C.A., Lal, Rattan, Madden, Patrick, Miller, Robert H., House, Gar (Eds.), Sustainable Agricultural Systems. Soil and Water Conservation Society, IA, pp. 637-654.

Landis, D.A., 1994. Arthropod sampling in agricultural landscapes: ecological considerations. In: Pedigo, Larry P., Buntin, G. David (Eds.), Handbook of Sampling Methods for Arthropods in Agriculture. CRC Press, Boca Raton, 714 pp.

Magdoff, F.R., 1992. Building Soils for Better Crops: Organic Matter Management. University of Nebraska Press, Lincoln, NE, 176 pp.

Marten, G.G., 1986. Traditional Agriculture in Southeast Asia: a Human Ecology Perspective. Westview Press, Boulder, CO, $358 \mathrm{pp}$.

Miller, R.H., 1990. Soil microbiological inputs for sustainable agriculture. In: Edwards,C.A., Lal, Rattan, Madden, Patrick, Miller, Robert H., House, Gar (Eds.), Sustainable Agricultural Systems. Soil and Water Conservation Society, IA, pp. 614623.

National Academy of Sciences, 1972. Genetic vulnerability of major crops. NAS, Washington, DC, $307 \mathrm{pp}$.

Palti, J., 1981. Cultural Practices and Infectious Crop Diseases. Springer, New York, 243 pp.

Perry, D.A., 1994. Forest Ecosystems. Johns Hopkins University Press, Baltimore, MD, 649 pp.

Paoletti, M.G., Foissner, W., Coleman, D. (Eds.), 1994. Soil Biota, Nutrient Cycling, and Farming Systems. Lewis Publishers, Boca Raton, 314 pp.

Reijntjes, C., Haverkort, B., Waters-Bayer, A., 1992. Farming for the Future: an Introduction to Low-External-Input and Sustainable Agriculture. Macmillan, London, 250 pp.

Schroth, M.N., Hancock, J.G., 1985. Soil antagonists in IPM. In: Hoy, M.A., Herzog, D.C. (Eds.), Biological Control in Agricultural IPM Systems. Academic Press, New York, pp. $415-431$.

Southwood, R.E., Way, M.J., 1970. Ecological background to pest management. In: Rabb, R.C., Guthrie, F.E. (Eds.), Concepts of Pest Management. North Carolina State University, Raleigh, NC, pp. 6-29.

Swift, M.J, Anderson, J.M., 1993. Biodiversity and ecosystem function in agroecosystems. In: Schultze, E., Mooney, H.A. (Eds.), Biodiversity and Ecosystem Function. Spinger, New York, pp. 57-83.

Tjamos, E.C., Papavizas, G.C., Cook, R.J., 1992. Biological Control of Plant Diseases: Progress and Challenges for the Future. NATO ASI Series, Plenum Press, New York, 462 pp.

Toledo, U.M., 1985. Ecologia y Autosuficiencia Alimentaria. Siglo XXI Editors, Mexico City, 118 pp.

Vandermeer, J., Perfecto, I., 1995. Breakfast of biodiversity: the truth about rainforest destruction. Food First Books, Oakland, $185 \mathrm{pp}$. 